\title{
Irish Nationalism in the Poetry of W.B. Yeats
}

Priyanka Maral

Assistant Professor

Department of English

K.N. Govt. P.G. College

Bhadohi, Uttar Pradesh, India

priyanka24maral@gmail.com

\section{Abstract}

W.B. Yeats was born in 1865 near Dublin in Ireland and through his literary work contributed in the cultural nationalism of Ireland. He had visions of a future Ireland that would eventually become the modern Ireland we know and love today. He attempted to bring the country together by replacing sectarian and class allegiances with a nationalistic one. When it came to nationalism, he tried to explain the significance of love and death. In this paper, I will try to discuss Irish nationalism in the poetry of Y eats.

Keywords: Nation, Ireland, Literary, Unify, Nationalism

W.B. Yeats was a public figure in Ireland before 1922. He became a Senator in the Irish Free State and in 1923 he was awarded the Nobel Prize for Literature. When it was declared that Yeats would be awarded the Nobel Prize for Literature, it was looked upon by people of the World as an attempt to recognize the Irish Free State. As Wade says: "Of course I know quite well that this honor is not given to me as an individual but as representative of a literary movement and a nation and I am glad to have it so. (Wade p. 701)

He had the knowledge of the history of Ireland as he had read Giambattista Vico and Arnold J. Toynbee. He used mythical interpretation for the progress of Irish civilization. According to Yeats the eighteenth century is regarded as the golden period in the Irish history 
because Tone, Emmet and Fitzgerald belonged to this period. Before meeting John O' Leary and other nationalist poets, his early poems were imitations of the romantic poets. As A. Norman Jeffares says "it is his active participation in politics and study of Irish history and literature that enabled him to choose the right path which led him to the desired goal" (Jeffares p. 35).

During this time, nationalists sang songs about ancient Ireland's glory in an attempt to arouse nationalistic sentiment among the populace. The poet was profoundly influenced by the efforts of nationalists. The poetry of Davis, Alligham, Mangan and Standish O' Grady inspired him. His sole aim of writing was the literary and cultural revival of Ireland. He defined Ireland as militant and fierce in his artful poetry "Popular Ballad Poetry of Ireland" written in 1887 , but it was published in 1889 , with the following words "behind Ireland, force and militant, is Ireland poetic and passionate, remembering idyllic, fanciful and always patriotic with this second Ireland only I have to do in this article" (Frayne p. 147).

In this article he wrote about the common Irish people and omitted Moore, Lever and Lover by saying "Moore lived in the drawing rooms" and "Lever and lover, kept apart by opinion from the body of the nation, and wrote ever with one eye on London" (Frayne p. 162).

He wrote in the English language but his poetry was Irish in content. He was an Anglo-Irish Protestant and belonged to a family who took interest in the Gaelic culture and were nationalist. Being an Anglo- Irish he supported Unionism but his nationalistic sentiment was against it. He was torn between these two feelings and unable to decide to support either of them. He was impatient when he married an English woman because his hatred for Britain was due to the suppression of Ireland by Britain which did not allow him to marry an English woman. 
He expressed his love for Ireland when he said in his Essays and Introduction "I owe my soul to Shakespeare, to Spenser, and to Blake, perhaps to William Morris, and to the English language in which I think, speak, and write that everything I love has come to me through English my hatred tortures me with love my love with hate ... Gaelic is my national language but is not my mother tongue" (Yeats p. 519).

He admired the poetry of the Young Irelanders like Thomas Davis' poem "A Nation Once Again" and James Clarence Mangan's poem "Dark Rosalem" because they tried to unite the people of Ireland as a nation. They used folklore in their poetry which showed their attachment to the native culture. It showed their main aim of writing poetry was to spread nationalistic sentiment among the people. After reading the poems of Mangan he abandoned the Keatsian concept of beauty in his poetry.

Thus, he tried to identify himself politically with the Young Irelanders. He wrote about Thomas Davis's poem "The Green above the Red" in his "September 1913" (Responsibilities). In his early poems he tried to include the Irish subject the nineteenth century and the twentieth century in the Cultural Revival. Yeats' contribution to the literature of Ireland was important in comparison to other Anglo-Irish artists of his age. The Gaelic texts were translated and works based on the ancient texts dealing with Irish people were popularized during the nineteenth century.

The British regarded themselves as superior and Irishmen as terrorists, lazy and dirty. Douglas Hyde, a Gaelic Senator tried to revive the feeling of pride among the Irishmen which had become latent due to colonial rule. It was Hyde, a Gaelic Senator, who was, as Jeffares says, "Yeats' first source of information about Irish oral tradition and texts of Irish poetry and legend." (Jeffares p. 26). He admired Hyde's use of Gaelic idiom and Tudor vocabulary, both of which Yeats called "distinctive" to English prose. 
Yeats wrote in English but his texts were based on the Gaelic texts. His first volume of poems contained a long narrative poem "The Wanderings of Oisin" (1889) from three the Gaelic poems about Oisin's exploits and from Michael Comyn's “Oisin’s Lay” (1760) based on the Finn Cycle of the Oisin story from the twelfth century. The commentary of Nuslas O' Cearnaigh on the texts which Yeats consulted, draws wide ranging spiritual parallels for what seems to be "the exotic aspects of Irish Gaelic literature" in Non-European cultures, especially India's ( Bramsback and Croghan p. 44).

His other poems like “The Madness of King Goll” (Crossways), based on O' Curry version of a tall in the Fenain cycle; "The Death of Aoife's" only as "A Faery Song" (The Rose) uses Diarmuid and Garinne story from the Fenian Cycle; "The Lullaby", "A Cradle Song" (The Rose) the last two lines from a Gaelic song and "The Host of the Air" (The Wind Among the Reeds) are based on a ballad as Yeats said was sung and translated to him by a woman at Ballisadar in Sligo.

The poem "The Madness of King Goll" is about a king named Goll who ruled from Ith to Erain. He ruled over human beings and animals when he got mad. In the first three stanzas the king narrates his glorious past and the poet praises him in hyperboles. In the next three stanzas, he describes his life during madness. He says when he was wandering he reached a town at night. He wanted to meet the people of the town but he could not meet them due to night. While he was roaming in the town he found a tympan and started singing of "some inhuman misery" but the wires broke and he starts wandering again:

I must wander wood and hill.

Through summer's heat and winter's cold. (Yeats p. 70-71)

As David Daiches says the tragedy of King Goll is his failure to make contact with the domestic life. His departure from domestic life to the wild nature is suggested by 
juxtaposition of contrasting images-"cushioned" and "otterskin", "fields" and "bubbling mire" and "keen eyes of men" and "keen stars" (Daiches p. 49).

His poem "The Stolen Child" is about the popular belief that fairies can take human beings to their land of heart's desire, their world is full of joy and happiness:

To and fro we leap

And chase the frothy bubbles,

While the world is full of troubles

And is anxious in its sleep. (Yeats p. 20-23)

It was believed that children are taken to fairy land by fairies because a child is innocent and has little knowledge of the real world. The fairies express their happiness over their success:

Away with us he's going,

The solemn-eyed:

He'll hear no more the lowing

Of the calves on the warm hillside

Or the kettle on the hob

Sing peace into his breast,

Or see the brown mice bob

Round and round the oatmeal-chest. (Yeats p. 67-74)

As Professor A.N. Jeffares comments in this poem ("The Stolen Child") marks the shift from Arcadian and Indian scenes to Irish-Yeats wrote later that for such reason as those in "Ireland and the arts". He convinced himself that he should never "go for the scenery of a poem to any country but my own, and I think that I shall hold to that conviction to the end" (Jeffares p. 13). 
He drew inspiration for his poem "Down by the Salley Gardens" from an old Irish song. It is an adaptation but it differs from the older Irish poem because it was based on corruption while Yeats' poem deals with the contrast between innocence and experience. As Yeats said in the footnote to the poem that it is "an attempt to reconstruct an old peasant woman who lived in a village of Ballysodare, Sligo often sings them to herself' (Jeffares p. 14).

This is yet another elegy. Monologue "An Irish Airman Foresees his Death". Robert Gregory is the speaker and he speaks from his grave as an imaginary speaker, a hero who chooses death "A lonely impulse of delight" instead to die from the hands of his own sides.

As a person who is fighting in war between Germany and Britain:

Those that I fight I do not hate,

Those that I guard I do not love. (Yeats p. 3-4)

Through these lines Yeats has tried to show the feelings of Irish soldiers who were fighting for the British against Germany in the First World War. The speaker of these lines says that he does not hate the country against whom he is fighting and at the same time he has no love for Britain for whose protection he is fighting. He says that the result of the war will not affect the lives of the Irish people who are leading a miserable life under the British rule. This poem was written on the insistence of Lady Gregory, the way she wanted her son to be remembered but Robert was supporter of the British rule in Ireland.

"Reprisals" (1921) is an opposite of the earlier poem. He says:

Half drunk or whole mad soldier

Are murdering your tenants

Where may new married women sit

And suckle children now? (Yeats p. 6-8) 
In this poem Yeats describes the ground situation in Ireland during the First World War. These lines describe the drunken British soldiers are murdering Irish tenants and there is no safety of women and children in Ireland. This poem was written when Robert Gregory was fighting for the British army in the First World War and one of his Irish tenants was killed by the British forces in Galway. His mother Lady Gregory was offended by the killing of her tenant.

Yeats described life in revolutionary Ireland after Easter 1916 in his "A Bunch of Martyrs" (1916) was the bomb and we are living in the explosion. As in his "A Prayer for my Daughter" in Michael Roberts and the Dancer:

Once more the storm is howling, and half hid

Under this cradle-hood and coverlid

My child sleeps on. (Yeats p. 1-3)

These lines reflect the frustration of the poet after the First World War. The World War ended in 1919 but Ireland remained disturbed due to internal conflicts. The poet is concerned about the future if his daughter Annie who was born in 1919. He wants his daughter to be safe and live in a peaceful atmosphere.

Yeats published his poem "Easter 1916" in 1920 in a British journal The New Statesman which was sympathetic to the Irish cause and for Terence Macswiney who was on a hunger strike in an Irish prison. It was published few days before his death after fasting for 74 days. This poem deals with Macswiney, his journey and martyrs of Easter 1916 are described. In the poem he says:

Hearts with one purpose alone

Through summer and winter seem

Enchanted to a stone

To trouble the living stream.(Yeats p. 41-44) 
He is trying to say the nationalists had one purpose in their mind during the rising, to liberate Ireland from the British rule. But their death has changed everything because now they are like stone which is not affected by any change and it is this quality which is stirring the heart of the Irish people.

In this poem, he remembers the people who lost their lives in 1916 rising. He admires the sacrifices of the Irish People in their struggle for independence over a long period.

And all this was done to gain support of the liberal public in Britain and America. He wanted to show that control of British over Ireland was morally and politically wrong. During this period revolutionaries were shopkeepers, schools teachers and clerks of Irish Catholic middle class about whom Yeats had not written.

His poem "Sixteen Dead Men" is a sequel of "Easter 1916", he refers to the sixteen men who were shot by the British forces and how this incident created a bitter ferment in Ireland "to stir the boiling pot?" He says that in this situation, a policy of compromise is out of the question. He does not want to wait till the defeat of Germany at the hands of British so that a decision on Irish independence can take place after the end of the war. According to him after the death of Pearse, the national revolutionaries are filled with the lofty spirit of Wolfe Tone and Lord Edward that they can achieve independence.

Yeats differed from Joyce because he was attached to the rural Ireland, with landlordism and peasantry while Joyce was attached more to the urban middle class. Yeats was involved in the political life before and after the departure of the British. He lived with his wife in Ireland during the Troubles of war, the Easter Rising 1916, the War of Independence 1919-1921 and during the Civil War 1922-23. He accepted the Senator's post in the Irish Parliament and remained a Senator till his death in 1939. He shared Nietzsche's view of catastrophes in Europe and was about to meet him. Ireland was affected by the First 
World War because it was a colony. He supported the creation of the Irish Free State in 1922. His nationalism was intact not like Joyce who was a critique of nationalism in his poems use of "I" does not negate "we" of nationalism.

Yeats' poems in The Tower describe the cultural fragmentation and political menace in Ireland.

The poems "Nineteen Hundred Nineteen" and "Meditations in Time of Civil War" are based on the historical and the political condition in Ireland during independence movement and civil war. He was involved in the politics of creation of the nation and after it also in September 1913 and Easter 1916 collapse. In "Nineteen Hundred and Nineteen" he saw how the progressive culture of Europe becomes the ground of the World War. It comments on the contemporary Irish situation and horror of war.

Humanitarian responses to the Irish Civil War are found in his "Meditations in Time of Civil War.". As he says:

An affable Irregular,

A heavily-built Falstaffian man,

Comes cracking jokes of civil war

As though to die by gunshot were

The finest play under the sun. (Yeats p. 128-132)

These lines show that the killing of innocent Irish men was an everyday affair in Ireland during the Civil War. In the poem he compares the honeybees which symbolizes as sweeteners to the Irish men whose minds are filled with hatred during the civil war.

In "Sailing to Byzantium" Yeats tries to come to terms with changes in Ireland as he says "That is no country for old" (p. 1). This poem tells us about a man who is stranger in his own country due to his old age. There is conflict between youth and old age in the poem. The 
poet in this poem expresses his desire to leave his country because it neglects "monuments of aging intellect" (Yeats p. 8).

In the poem "The Rose", the rose symbolizes Ireland and a more universal idea of spiritual and intellectual beauty.

An ancient bridge, and a more ancient tower,

A farmhouse that is sheltered by its wall,

An acre of stony ground

Where the symbolic rose can break in flower. ( Yeats p. 11-15)

Yeats published his poem "Easter 1916" in 1920 in a British journal The New Statesman which was sympathetic to the Irish cause and for Terence Macswiney who was on a hunger strike in an Irish prison. It was published few days before his death after fasting for 74 days. This poem deals with Macswiney, his journey and martyrs of Easter 1916 are described. In the poem he says:

Hearts with one purpose alone

Through summer and winter seem

Enchanted to a stone

To trouble the living stream.(Yeats p. 41-44)

He is trying to say the nationalists had one purpose in their mind during the rising, to liberate Ireland from the British rule. But their death has changed everything because now they are like stone which is not affected by any change and it is this quality which is stirring the heart of the Irish people.

In this poem, he remembers the people who lost their lives in 1916 rising. He admires the sacrifices of the Irish People in their struggle for independence over a long period. 
And all this was done to gain support of the liberal public in Britain and America. He wanted to show that control of British over Ireland is morally and politically wrong. During this period revolutionaries were shopkeepers, schools teachers and clerks of Irish Catholic middle class about whom Yeats had not written.

His poem "Sixteen Dead Men" is a sequel of "Easter 1916", he refers to the sixteen men who were shot by the British forces and how this incident created a bitter ferment in Ireland "to stir the boiling pot?" He says that in this situation, a policy of compromise is out of the question. He does not want to wait till the defeat of Germany at the hands of British so that a decision on Irish independence can take place after the end of the war. According to him after the death of Pearse, the national revolutionaries are filled with the lofty spirit of Wolfe Tone and Lord Edward that they can achieve independence.

Thus, it can be said that Yeats' poetry is a representation of Irish nationalism in Ireland. He wrote poetry not for art's sake but to inspire the people of his country. He used of Irish myth and legends in his poems to depict the cultural history of Ireland. In his poem "Easter 1916," he expressed admiration for the Easter Rising martyrs' sacrifice and hope that Ireland would one day be free of British rule. His poems are an interpretation of the political events of his period; they inspired the people of Ireland during the Irish nationalism. 


\section{References}

Cormack, W.J.C. and Stead, Alastaire. James Joyce and Modern Literature. London: Routledge,1982. Print.

David, Daiches. “The Practical Visionary”, Encounter 9.3 (1962) 124-29. Print.

Frayne, John P. ed. The Uncollected Prose of W.B. Yeats. 1 vol. London: Macmillan, 1970.Print.

Jeffares, A. Norman. W.B. Yeats: A Biography. London: Arena, 1990.Print.

Wade, Allan. ed. The Letters of W. B. Yeats. London: Rupert Hart-Davis, 1954. Print.

Yeats,W.B. Letters on Poetry from W.B. Yeats to Dorothy Welllesley. London: University Press, 1940. Print.

Yeats,W.B. The Collected Poems of W.B. Yeats. London: Macmillan, 1950. Print. 